\title{
The value of near-peer teaching in the medical curriculum: a medical student's perspective
}

This article was published in the following Dove Press journal:

Advances in Medical Education and Practice

\section{Ishar Alexander Kalsi}

GKT School of Medical Education, Faculty of Life Sciences and Medicine, King's College London, London, UK

Correspondence: Ishar Alexander Kalsi GKT School of Medical Education, Faculty of Life Sciences and Medicine, King's College London, Hodgkin Building, Newcomen Street, London SEI IUL, UK Email ishar.kalsi@kcl.ac.uk

\section{Dear editor}

It is with both interest and sympathy that I read the research letter published by Sonagara et $\mathrm{al}^{1}$ about the numerous advantages of near-peer teaching and the recommendation that it should be part of the medical syllabus. As a medical student at King's College London, I am a member of a near-peer learning scheme. Our peer-assisted learning (PAL) scheme is designed to complement the material taught in lectures. In groups of five students, we select a lecture to revise together with our PAL tutors (senior medical students) for one hour weekly. A self-made presentation, mock exam questions, and diagrams are commonly used as material in PAL sessions. It is the PAL tutors themselves who generate this material, while balancing their own study needs; thus, I find credit in the statement of how time management skills improve through peer teaching.

However, I would like to draw attention to potential drawbacks of near-peer teaching schemes not mentioned in the letter. From my experience, it is common for lecturers and tutors to use technical jargon specific to particular research fields, since they are likely to have published research in those field themselves. During PAL sessions, technical jargon is replaced with plain language, offering explanations that are easily understood. Furthermore, the teaching material may not be updated frequently to incorporate the most current research.

One potential overlooked outcome of simplification and dated information is that near-peer teachers may inadvertently dissuade medical students from exploring research paths. While such schemes can be effective in filling knowledge gaps, ${ }^{2}$ they may be less effective in habituating the reading of current research and understanding it with sufficient ease. Although near-peer teaching can make material easier to grasp, it might also decrease the desire to pursue the path of research, since students would not have been exposed sufficiently to "apprenticeship" in research. ${ }^{3}$ Near-peer teaching is less likely to be as effective as lead lectures, tutorials, workshops, etc currently endorsed by medical schools in exposing medical students onto research. Those who want to pursue a career in research may be subtly deterred from lack of exposure.

No doubt research is important for medicine and medical students strive to join research programs. In the United States, for example, $65 \%$ of medical students would prefer to pursue research for a year, even if they have a confirmed place in a residency program. ${ }^{4}$ If medicine is indeed driven forward by research, it would make sense 
to have current doctors and researchers conduct lectures and tutorials, as they would have the added experience of research to share.

Furthermore, if peer teaching was to be part of formal teaching, could it rise to the level of tutorials, or would it become an inferior-grade tutorial? For the former to happen, near-peer teachers would have to extend their preparations considerably. This could create a substantial burden, ultimately decreasing their desire to participate in such schemes to the detriment of current beneficiaries. In sum, I would support retaining the current structure and scope of near-peer teaching schemes.

\section{Disclosure}

The author reports no conflicts of interest in this communication.

\section{References}

1. Sonagara VJ, Santhirakumaran S, Kalkat HS. The value of near-peer teaching in the medical curriculum. Adv Med Educ Pract. 2018;9:63-64.

2. Reidlinger DP, Lawrence J, Thomas JE, Whelan K. Peer-assisted learning and small-group teaching to improve practice placement quality and capacity in dietetics. Nutr Diet. 2017;74(4):349-356.

3. Dornan T. Osler, Flexner, apprenticeship and "the new medical education." J R Soc Med. 2005;98(3):91-95.

4. Pathipati AS, Taleghani N. Research in medical school: a survey evaluating why medical students take research years. Cureus. 2016;8(8):e741.

Dove Medical Press encourages responsible, free and frank academic debate. The content of the Advances in Medical Education and Practice 'letters to the editor' section does not necessarily represent the views of Dove Medical Press, its officers, agents, employees, related entities or the Advances in Medical Education and Practice editors. While all reasonable steps have been taken to confirm the content of each letter, Dove Medical Press accepts no liability in respect of the content of any letter, nor is it responsible for the content and accuracy of any letter to the editor.

\section{Publish your work in this journal}

Advances in Medical Education and Practice is an international, peerreviewed, open access journal that aims to present and publish research on Medical Education covering medical, dental, nursing and allied health care professional education. The journal covers undergraduate education, postgraduate training and continuing medical education including emerging trends and innovative models linking education, research, and health care services. The manuscript management system is completely online and includes a very quick and fair peer-review system. Visit http://www.dovepress.com/testimonials.php to read real quotes from published authors.

Submit your manuscript here: http://www.dovepress.com/advances-in-medical-education-and-practice-journal 